\title{
Suppression of green mold disease on oak mushroom cultivation by antifungal peptides
}

\author{
Hyoung-Jin Lee ${ }^{1}$ (D) $\cdot$ Yeong-Bae Yun ${ }^{1}$ (D) Jeong-Hoon Huh ${ }^{1}$ (D) $\cdot$ Young-Kee Kim $^{1}$ (iD \\ 항진균성 펩티드에 의한 표고버섯 푸른곰팡이병의 억제
}

이형진 ${ }^{1} \cdot$ 윤영배 $^{1} \cdot$ 허정훈 $^{1} \cdot$ 김영기 $^{1}$

Received: 6 May 2017 / Accepted: 16 May 2017 / Published Online: 30 June 2017

(C) The Korean Society for Applied Biological Chemistry 2017

\begin{abstract}
Contamination and growth of Trichoderma, a green mold, on the oak log and wooden chip or sawdust media can severely inhibit the growth of oak mushroom. Chemicals including pesticides and antibiotics are generally not allowed for the control of green mold disease during mushroom cultivation. In this study, bacterial pathogens causing blotch disease on the oyster mushrooms were isolated and their peptide toxins were purified for the control of green mold disease. Strains of Pseudomonas tolaasii secret various peptide toxins, tolaasin and its structural analogues, having antifungal activities. These peptides have shown no effects on the growth of oak mushrooms. When the peptide toxins were applied to the green mold, Trichoderma harzianum H1, they inhibited the growth of green molds. Among the 20 strains of peptide-forming $P$. tolaasii, strong, moderate, and weak antifungal activities were measured from 8,5 , and 7 strains, respectively. During oak mushroom cultivation, bacterial culture supernatants containing the peptide toxins were sprayed on the aerial mycelia of green molds grown on the surface of sawdust media. The culture supernatants were able to suppress the fungal growth of green molds while no effect was observed on the mushroom growth and production. They changed the color of molds from
\end{abstract}

Young-Kee $\operatorname{Kim}(\bowtie)$

E-mail: ykkim10@cbnu.ac.kr

${ }^{1}$ Department of Environmental and Biological Chemistry, Chungbuk National University, Cheongju, Chungbuk 28644, Republic of Korea

This is an Open Access article distributed under the terms of the Creative Commons Attribution Non-Commercial License (http://creativecommons. org/licenses/by-nc/3.0/) which permits unrestricted non-commercial use, distribution, and reproduction in any medium, provided the original work is properly cited. white aerial mycelium into yellowish dried scab, representing the powerful anti-fungal and sterilization activities of peptide toxins.

Keywords Antifungal peptide toxins - Green mold disease · Oak mushroom $\cdot$ Pseudomonas tolaasii $\cdot$ Tolaasin $\cdot$ Trichoderma harzianum

\section{서 론}

식용 버섯은 혈중 콜레스테롤 저하 및 항암 효과 등을 갖고 있 어 유효성분 등에 대한 많은 연구가 진행되어 왔다. 그 중 담 자균강 주름버섯목 느타리과 잣버섯속에 속하는 표고버섯 (Lentinus edodes)은 맛이 좋은 3대 버섯의 하나로 널리 알려져 있으며, 또한 면역강화 등 건강에 이로운 여러 효능이 알려져 우수한 식재료로 이용되고 있다(Yamamoto 등, 1997). 대표적으 로 표고버섯으로부터 분리한 lentinan은 항암보조제로 시판되고 있으며(Sullivan 등, 2006), 그 외에도 당뇨병의 개선 등 성인병 에 효과가 크고(Hikino 등, 1985), 섬유질과 비타민이 풍부하여 혈중 콜레스테롤과 체중감소에 효과적인(Kweon 등, 2002) 다기 능 신선종합식품으로 밝혀져 선호도가 매우 높은 버섯이다(Bae 등, 2007).

다양한 장점에도 불구하고 국내 표고버섯의 생산량은 꾸준히 감소하고 있으며, 여러 이유가 있으나 푸른곰팡이병의 빈번한 발생도 재배기피의 중요한 원인중의 하나이다(Bak과 Kwon 2005; Miyazaki 등, 2009). 푸른곰팡이병은 인공재배를 하는 양 송이버섯, 느타리버섯, 표고버섯 등 모든 버섯에서 발생하는 병 해이다. 균사 생장기에는 백색이지만 포자가 형성되면서 푸른색 을 띠기 때문에 푸른곰팡이병으로 불린다. 푸른곰팡이는 목재 성분을 부패시키고, 표고균사에 직접 기생하여 균사를 사멸시키 
며, 독소(gliotoxin)를 분비하여 균사생장 및 버섯의 발생을 억 제한다(Seaby 1998; Ait-Lahsen 등, 2001). 푸른곰팡이의 생장 을 위한 적정온도는 $25-30{ }^{\circ} \mathrm{C}$ 이며, 습도는 $80 \%$ 이상으로 관수 시설을 사용하는 재배사의 특성상 연중 발생하며, 주로 여름 장 마철에 빈번하게 발병한다. 푸른곰팡이병을 유발하는 균류는 30 여 종이 있으나, 국내에서 표고버섯 재배시 피해를 주는 주된 푸른곰팡이는 Trichoderma 속으로 T. harzianum, T. virens, T. viride, T. longibrachiatum, T. konigii, T. polysporum 등이 알 려져 있다(Kim 등, 2012).

푸른곰팡이 Trichoderma에 의한 피해는 국내뿐만 아니라 외 국에서도 자주 나타나, 표고생산량이 많은 일본이나 중국은 물 론 유럽, 이란, 캐나다, 미국 등에서 푸른곰팡이에 의한 피해가 보고되었다(Hatvani 등, 2012; Wang 등, 2016). 그러나 표고버 섯은 우수한 신선식품이기에 푸름곰팡이의 방제를 위하여 화학 약품이나 농약 등의 약제를 쉽게 사용할 수 없는 실정이다. 현 재는 푸른곰팡이의 방제를 위하여 benomyl 등의 농약류를 살 포하기도 하나 예방하는 것이 최선으로 생각되고 있다(Jhune 등, 1990). 농약 등 화학약품에 의한 방제는 약제에 대한 내성 균의 발생, 비표적생물에 대한 독성, 환경문제 등을 일으킬 수 있고(Lee 등, 2009), 잔류로 인해 축적되기 때문에(Lee 등, 2008), 표고버섯 재배특성상 원목이나 톱밥 배지에 사용이 어려 운 실정이다.

본 연구에서는 항진균 활성을 가지고 있는 펩티드를 이용하 여 표고버섯 재배에서 자주 나타나는 푸른곰팡이병을 방제하고 자 하였다. 톨라신을 포함한 펩티드류는 표고버섯을 제외한 재 배버섯 대부분에 갈반병을 유발하나 표고버섯에서는 갈반병을 발생시키지 않아 표고버섯 재배에 해가 없음이 잘 밝혀져 있다 (Cho 등, 2007). 이에 따라 항진균 펩티드를 생성하는 다양한 P. tolaasii 균주를 선별하여 푸른곰팡이에 대한 억제 특성을 조 사하였다.

\section{재료 및 방법}

\section{항진균 펩티드 생산균주의 분리}

항진균 펩티드 생산균주는 갈반병에 감염된 버섯으로부터 Cho 등(2000)의 방법에 따라 분리하였다. 갈반이 형성된 느타리버섯 조직 약 $1 \mathrm{~cm}^{2}$ 를 멸균한 칼로 잘라내어 $10 \mathrm{~mL}$ 멸균수에 넣고 분쇄한 후에 멸균수로 희석하였다. 희석액 $200 \mu \mathrm{L}$ 를 Pseudomonas Agar F (PAF; Bacto-peptone $10 \mathrm{~g}$, Bacto-tryptone $10 \mathrm{~g}, \mathrm{~K}_{2} \mathrm{HPO}_{4}$ $1.5 \mathrm{~g}, \mathrm{MgSO}_{4} 1.5 \mathrm{~g}$, glycerol $10 \mathrm{~mL}$, agar $15 \mathrm{~g} / 1 \mathrm{~L}$ 증류수) 평판배지 위에 도말하고, $25^{\circ} \mathrm{C}$ 에서 48 시간 배양하여 자외선등 아래에서 형광성을 확인하고 선별한 세균들은 버섯조직함몰검 정법(pitting test)을 이용하여 병원성을 평가하였다(Kim 등, 1994). 분리한 균은 glycerol $20 \%$ 를 함유한 PAF 저장배지 $1.5 \mathrm{~mL}$ 에 저장하여 초저온냉동고 $\left(-70{ }^{\circ} \mathrm{C}\right)$ 에 보관하였다.

\section{푸른곰팡이의 분리}

표고버섯에 피해를 주는 푸른곰팡이는 버섯 종균 생산농가 또 는 재배농가에서 병이 발생한 톱밥배지를 수집하여 푸른곰팡이 가 발생한 부분 약 $1 \mathrm{~cm}^{2}$ 를 멸균한 칼로 잘라내어 멸균수 40 $\mathrm{mL}$ 에 넣고 분쇄한 후에 면직포를 이용하여 톱밥배지 및 불순
물을 제거하였다. 이 혼합액을 멸균수로 희석하고, Potato dextrose $\operatorname{agar}(\mathrm{PDA})$ 평판배지 위에 도말하여 $27^{\circ} \mathrm{C}$ 에서 $48-60$ 시간 배양 한 후, colony 형성을 확인하여 분리하였다. 분리한 균주는 다 시 $\mathrm{PDA}$ 평판배지 위에 접종하여 48-72시간 동안 배양하여 균 주가 충분히 자란 후, 배지를 멸균수 $30 \mathrm{~mL}$ 에 넣어 현탁하고, 면 직포에 여과하여 포자현탁액을 얻었다. 포자는 $20 \%$ glycerol 수 용액에 현탁하여 초저온냉동고 $\left(-70{ }^{\circ} \mathrm{C}\right)$ 에 저장하였다.

\section{항진균 활성 측정 방법}

항진균 활성을 측정하기 위하여 PDA 고체배지에 Trichoderma harzianum $\mathrm{H} 1$ 균주 배양액을 배지의 우측에 $30 \mu \mathrm{L}$ 접종하고 $2-3 \mathrm{~cm}$ 떨어진 좌측에 균주 배양액을 원심분리하여 균주는 침 전시키고 항진균 펩티드를 포함하는 상징액만 취하여 원액 50 $\mu \mathrm{L}$ 를 점적한 필터디스크를 위치한 다음 배양하였다. 푸른곰팡 이는 모든 방향으로 성장하나 항진균 펩티드를 함유한 디스크 부위에는 성장하지 못하여, 균사의 비대칭 성장을 보였다. 이 때 곰팡이 성장이 저해된 부분인 비대칭 부위의 면적을 측정하 였으며, 곰팡이 생육억제 면적이 클수록 푸른곰팡이에 대한 펩 티드의 항진균 활성이 우수한 것으로 평가하였다. 억제면적은 Adobe photoshop CS 프로그램을 이용하여 측정하였다.

\section{톱밥배지에서 푸른곰팡이 발생면적 측정}

톱밥배지에서의 항진균 펩티드의 항진균 활성을 측정하기 위하 여 곰팡이가 발생한 톱밥배지의 표면이 젖도록 항진균 펩티드 를 1회 처리하였다. 곰팡이 억제 효과를 측정하기 위해서는 표 고버섯을 재배하는 중에 톱밥배지에서 푸른곰팡이의 발생면적 을 평가하여야 하며, 평가방법을 개발하여 '색상선택법'으로 명 명하였다. 톱밥배지 전체를 사진으로 찍은 후 사진의 색상을 컴 퓨터로 분석하면 RGB (red, green, blue) 세 가지 색상으로 분 석이 되며, 이는 각각 0-255 사이의 값을 가지게 된다. 이 세 가지 색상의 조합으로 모든 색상이 표현되는데 본 실험에서 사 용한 푸른곰팡이의 색상 범위는 R: $100-140, \mathrm{G}: 110-150, \mathrm{~B}$ : 110-150이며, 이는 사진을 찍을 때의 날씨 또는 시간에 따라 차 이가 있기 때문에 약간의 변화를 주며 면적을 측정하였다. Adobe photoshop CS 프로그램을 이용하여 위의 색상범위를 선 택하고 푸른 색상범위의 색을 가지고 있는 면적이 표현이 되면, 이의 픽셀수를 계산하여 곰팡이의 발생면적의 변화를 측정하였다.

\section{결과 및 고찰}

\section{푸른곰팡이 염기서열 분석에 의한 동정}

표고버섯에 피해를 입히는 다양한 푸른곰팡이는 버섯 종균 생 산농가나 표고버섯 재배농가에서 병이 발생하여 폐기된 톱밥배 지를 수거하여 분리하였다. 대상지는 본 연구를 수행한 충북 청 주시 문의면 품곡리 버섯재배사(MY), 문의면 두모리 버섯재배 사(D), 남일면 이원농산 재배사(H), 보은의 속리산농원 재배사 $(\mathrm{BE})$, 충남 청양의 대박농산 재배사 $(\mathrm{CY})$ 등이다. 푸른곰팡이병 에 걸린 톱밥배지로부터 얻은 시료 중 총 15 개의 시료에서 푸 른곰팡이를 확인하였다.

곰팡이의 동정은 Internal transcribed spacer 염기서열 분석을 통하여 이루어졌으며(Miyazaki와 Tsunoda 2003; Watanabe 등, 


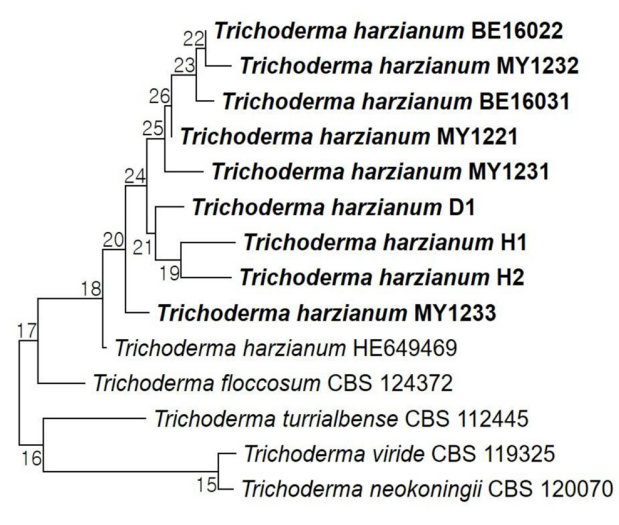

0.01

Fig. 1 Phylogenetic analysis of the isolated green mold strains of Trichoderma harzianum

2005), 이를 통하여 15개의 시료는 Trichoderma harzianum 9종, Trichoderma atroviride 3종, Penicillium brevicompacum 3종으 로 동정되었고, 이들 중 T. harzianum 에 속하는 변종은 phylogenetic 분석결과에 따라 분류되었다(Fig. 1). 각각의 동정 은 eztaxon (ezbiocloud.net/eztaxon)을 이용하였으며, 모두 98\% 이상의 염기 상동성을 보였다. 특히, T. harzianum 푸른곰팡이 균주는 수집한 병원성 균주의 절반 이상을 차지하였고 발견 지 역도 다양하였다. 이를 통해 T. harzianum이 충북지역의 표고버 섯 재배농가에 널리 분포되어 많은 피해를 주는 원인균임을 확 인하였다. T. harzianum에 의한 피해사례는 양송이, 느타리, 표 고버섯 모두에 걸친 여러 연구에서 보고되었다(Hatvani 등, 2007).

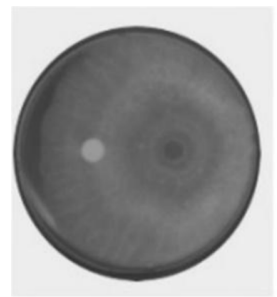

Control

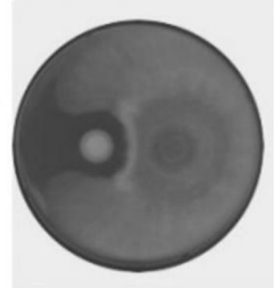

6264

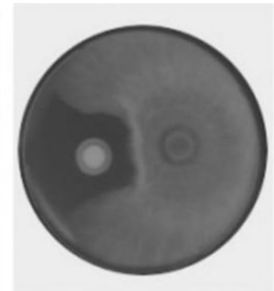

HK2

\section{푸른곰팡이 생육 억제 효과}

항진균 펩티드에 의한 항진균 활성은 앞서 동정한 다른 곰팡이 에서도 나타났지만, 가장 빈번하게 발생하는 T. harzianum을 이 용하여 실험을 수행하였다. 농도를 $0.2-0.5$ 배로 희석한 PDA 배 지에서 푸른곰팡이 T. harzianum $\mathrm{H} 1$ 을 배양하며, 항진균성 펩 티드를 생산하는 20 균주의 항곰팡이 효과를 측정하였다. 항진 균성 펩티드를 생산하여 갈반병을 유발하는 Pseudomonas tolaasii 균주는 유전자 분석과 병리학적 및 생화학적 특성에 따 라 $\mathrm{P} 1 \alpha, \mathrm{P} 1 \beta, \mathrm{P} 1 \gamma$ 그룹으로 분류하였고, $\mathrm{P} 1 \alpha$ 그룹은 6264 균 주를 포함하여 6 균주, $\mathrm{P} 1 \beta$ 그룹과 $\mathrm{P} 1 \gamma$ 그룹은 각각 13 균주 와 1 균주를 포함한다(Yun 등, 2013). P1 $\alpha$ 그룹에 속하는 $P$. tolaasii 6264, HK2, HK4 균주의 배양액을 분리 · 농축하여 PDA 배지상에서 푸른곰팡이 T. harzianum $\mathrm{H1}$ 균주와 대치 배 양하였을 때, 처리한 배양 농축액 주위에는 곰팡이의 균사 성 장이 완전히 억제되는 것을 확인하였다(Fig. 2). P. tolaasii 6264 균주를 포함한 HK1부터 HK23 균주들을 T. harzianum $\mathrm{H} 1$ 균주와 대치 배양하며 푸른곰팡이 $\mathrm{H} 1$ 균주의 생육 억제 효 과를 측정하여 Table 1에 정리하였다.

총 20종의 Pseudomonas tolaasii 균주 모두 푸른곰팡이를 억제 하는 효과를 보였지만, 그 중 가장 강력한 항진균 활성은 $P$. tolaasii 6264, HK2, HK4 등 주로 $\mathrm{P} 1 \alpha$ 그룹의 균주에서 얻어졌 다. 일부 $\mathrm{P} 1 \beta$ 그룹 균주에서도 좋은 활성을 보였으나, $\mathrm{P} 1 \beta$ 그룹 균주들은 적혈구를 이용한 용혈활성을 보이지 않아(Yun 등, 2013), 세포독성 측정에 어려움이 많으므로 실제 사용은 제한적이었다. 대치 배양 실험에서 항진균 효과가 우수한 균주는 $6264, \mathrm{HK} 2$, $\mathrm{HK} 3, \mathrm{HK} 4, \mathrm{HK} 5, \mathrm{HK} 11, \mathrm{HK} 12, \mathrm{HK} 16$ 균주들로 8 균주가 확인 되었다. 항진균 효과가 비교적 좋은 균으로 $\mathrm{HK} 14$ 등 5 균주, 항 진균 효과가 약한 균주로는 $\mathrm{HK} 1$ 등 7 균주가 확인되었다.

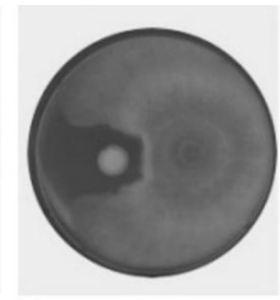

HK4

Fig. 2 Antifungal effects of the culture supernatants of P. tolaasii strains. Growth inhibitions of T. harzianum H1 strain were measured in the presence of culture supernatants of $P$. tolaasii 6264, HK2, and HK4. Culture supernatants were applied on the filter paper disc

Table 1 Antifungal activities of various strains of Pseudomonas tolaasii

\begin{tabular}{llllllllllllll}
\hline \\
\multirow{2}{*}{ Fungal strain }
\end{tabular}

Antifungal activity; +++: strong, ++: moderate, + : weak 


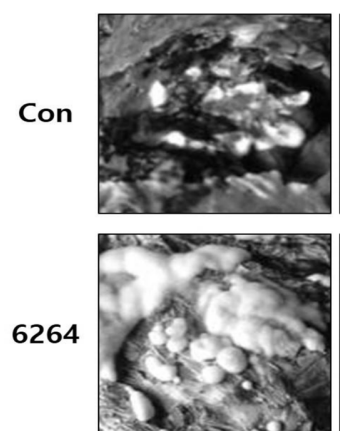

Day 0

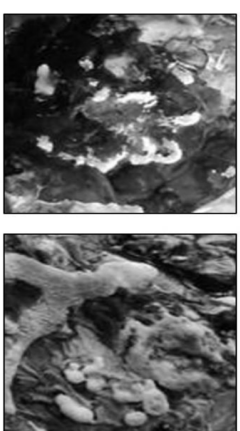

Day 2
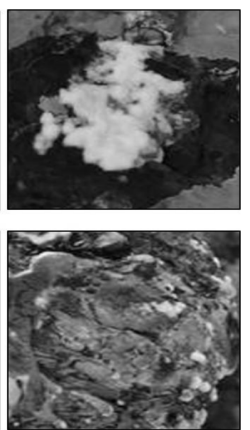

Day 6
Fig. 3 Sterilization of $T$. harzianum by the antifungal peptide toxins. The culture supernatant of $P$. tolaasii 6264 was sprayed on the green mold mycelia grown on the surface of sawdust media at day 0

\section{톱밥배지에서의 항진균 효과}

표고버섯 톱밥배지를 이용하여 표고버섯 재배 중에 항진균성 펩 티드의 항곰팡이 효과를 측정하였다. 1 주기 버섯 생산 후 톱밥 배지에 푸른곰팡이 포자를 접종하고 건조과정을 거쳐 2 주기 생 산을 시작하였을 때, 표고버섯이 발이하기 전에 푸른곰팡이가 모든 톱밥배지에서 발생하였다. 이것은 1 주기 수확 후, 표고버 섯 종균의 세력이 약해진 2 주기에 들어 접종한 푸른곰팡이의 포자가 전체 재배사에서 발아한 것으로, 대량 발생한 곰팡이와 접종한 푸른곰팡이 $\mathrm{H} 1$ 균주의 유전자 비교로 동일한 푸른곰팡 이임을 확인하였다.

발생한 푸른곰팡이를 방제하기 위하여 우수한 항진균 활성을 보이는 $\mathrm{P} 1 \alpha$ 그룹의 6264와 HK2 균주, $\mathrm{P} 1 \beta$ 그룹의 HK11 균 주, $\mathrm{P} 1 \gamma$ 그룹의 $\mathrm{HK} 23$ 균주의 효과를 측정하였다. 먼저, 항진균 펩티드를 포함하는 각각의 균주배양액을 분무하여 톱밥배지 전 반에 처리하고, 2 일차와 6 일차에 사진을 촬영하여 푸른곰팡이 발생면적의 감소 여부를 측정하였다. 대조구에는 PAF 배지액만 을 처리하였다. 대조구의 경우 푸른곰팡이의 생육은 2 일째에 처 음과 큰 차이가 없었으나, 시간이 경과함에 따라 6 일째는 푸른 곰팡이의 생육이 증가하여 흰색의 균사가 톱밥배지 표면에 전 체적으로 퍼졌고, 균사 발생 면적은 약 $50 \%$ 증가하였다. 반면, P. tolaasii 6264 배양액 처리구는 처리 당일에 푸른곰팡이 균사 가 대조구보다 더 넓었으나, 2 일차에 푸른곰팡이의 면적은 현 저히 줄어 처음 곰팡이 면적의 $50 \%$ 이하로 감소하였고, 푸른 곰팡이가 말라붙어 딱지와 같은 부위가 형성되었다. 6 일차에 푸 른곰팡이의 생육은 완전히 억제되었고, 원래 푸른색으로 나타났 던 곰팡이 부위는 딱지 등의 형성으로 쇠퇴하였다(Fig. 3). 이 때, 표고버섯 자실체는 정상적으로 발이되고 성장하여, 표고버 섯의 수확이 가능하였다.

대조구에서 푸른곰팡이의 증식과 비교하여 항진균 펩티드 처 리구에서 푸른곰팡이의 발생면적이 크게 감소한 결과는 항진균 펩티드가 푸른곰팡이의 생육 억제에 큰 효과가 있음을 보이는 결과이다. 이 기간 중에 표고버섯은 대조구와 처리구 모두에서 발이되고 성장하여 수확까지 가능하였으나, 이후 대조구에서는 푸른곰팡이의 발생이 증가하여 버섯의 발이와 생장이 크게 저 해되었고 더 이상의 버섯 생산이 불가능하였다. 푸른곰팡이의 발생은 2주기에서 3주기로 수확이 진행될수록 증가하여 전체적

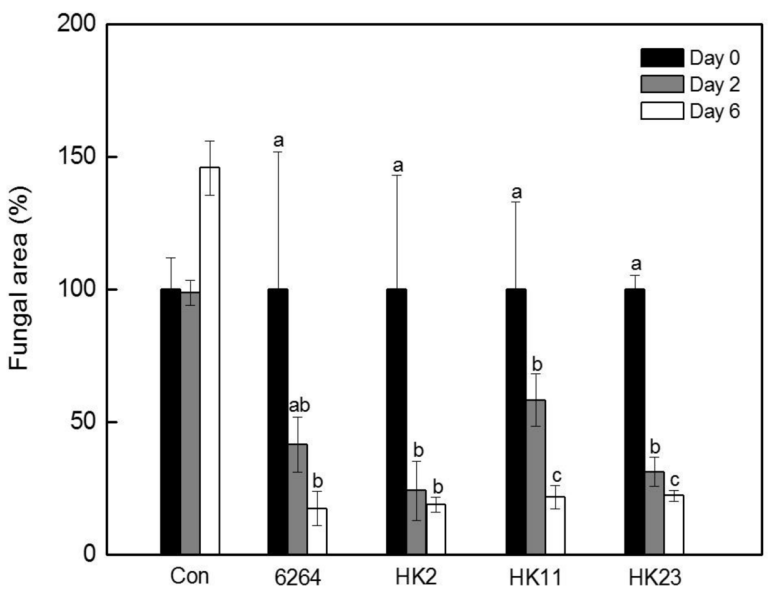

Fig. 4 Suppressions of green molds by the peptide toxins. Culture supernatants of the indicated $P$. tolaasii strains were sprayed on the mycelia of $T$. harzianum $\mathrm{H} 1$ at day 0 . Data are mean $\pm \mathrm{SE}$ (bars) percentage of the results from three replicates. The same letters are not statistically significant at $p<0.05$ (Tukey's Test)

으로 수확량을 크게 감소시키는 것으로 알려져 있다. 따라서, 생산주기를 더할수록 성공적인 표고버섯 생산을 위해서는 푸른 곰팡이의 발생을 억제하는 것이 중요하고, 톨라신을 포함한 항 진균성 펩티드 사용은 친환경적으로 이러한 목적을 이룰 수 있 을 것으로 판단된다.

P. tolaasii HK2, HK11, HK23 균주 배양액을 처리한 시험구 에서도 P. tolaasii 6264 균주 배양액을 처리한 시험구와 유사 한 결과를 얻었다(Fig. 4). HK2 균주 배양액 처리구에서 시간 의 경과에 따라 푸른곰팡이 발생면적이 현저하게 감소하는 것 이 관측되었다. 톱밥배지에서 푸른곰팡이의 균사는 항진균 펩티 드의 처리로 딱지같은 잔재로 남아 푸르게 나타났고, 시간 경 과에 따라 푸른곰팡이는 거의 사라지는 것을 확인하였다. HK11 균주와 $\mathrm{HK} 23$ 균주는 각각 $\mathrm{P} 1 \beta$ 와 $\mathrm{P} 1 \gamma$ 그룹 대표균주로 재배실 험에 사용되었고, 특히 두 균주 모두 PDA 배지상에서와 같이 톱밥배지 재배실험에서도 푸른곰팡이 억제 효과가 우수하게 나 타났다. 항진균 펩티드를 처리한 후 푸른곰팡이의 발생 면적을 색상선택법을 이용하여 평가하였을 때, 처리한 첫 날의 곰팡이 양을 $100 \%$ 로 하여 2 일과 6 일차에 푸른곰팡이 잔존 면적을 표 기하면, 6 일째에는 $20 \%$ 전후까지 줄어드는 것을 확인하였다. 이 때 남아있는 곰팡이 균사도 딱지를 형성하여 완전히 사멸된 것으로 판단되었다. 반면, 대조구의 경우는 푸른곰팡이의 생육 면적이 계속 증가하였다. 항진균 펩티드를 처리하였을 경우에는 모든 실험에서 푸른곰팡이의 생육 면적이 급격하게 감소하여, 톱밥배지를 이용한 표고버섯 재배에서 펩티드의 항진균 활성이 크게 나타남을 확인하였다.

이러한 결과는 P. tolaasii 균주들이 생산하는 톨라신을 포함 하는 펩티드류가 표고버섯 생산에 영향을 주지 않고 푸른곰팡 이의 균사 생육을 선택적으로 억제함을 보이는 것이다. 따라서, 톨라신류 펩티드의 특성을 밝히고 항진균 펩티드의 효과를 높 이는 처리방법을 개발한다면, 표고버섯 재배시 나타나는 푸른곰 팡이의 피해를 크게 줄일 수 있을 것이다. 


\section{초 록}

원목과 톱밥배지에서 푸른곰팡이의 오염과 성장은 표고버섯의 생장을 심하게 저해할 수 있다. 표고버섯 재배에서 푸른곰팡이 병의 방제를 위하여 농약과 항생제와 같은 화학 약품의 사용은 일반적으로 허용되지 않는다. 본 연구에서는 푸른곰팡이병의 방 제를 위하여 느타리버섯에서 갈반병을 일으키는 세균성 병원균 을 분리하고 이들의 펩티드 독소를 분리하였다. Pseudomonas tolaasii 균주들은 항진균 활성을 갖는 톨라신 및 이와 구조적 유사체인 다양한 펩티드 독소를 분비한다. 이러한 펩터드들은 표고버섯의 생장에는 영향을 주지 않는다는 것이 알려져 있다. 펩티드 독소들을 Trichoderma harzianum $\mathrm{H1}$ 푸른곰팡이에 처 리하였을 때, 푸른곰팡이의 성장을 저해하였다. 펩티드를 분비 하는 20 종의 P. tolaasii 균주 중에서 강, 중, 약의 항진균 활 성을 가진 균주의 수는 각각 $8,5,7$ 종으로 나타났다. 표고버 섯을 재배하는 동안에, 펩티드 독소를 함유한 세균 배양액에서 세균을 제거한 배양원액을 톱밥배지 표면에 자란 푸른곰팡이 균 사에 분무하였다. 배양원액은 푸른곰팡이의 성장은 억제할 수 있는 반면, 표고버섯 생장과 생산에는 영향을 주지 않았다. 펩 티드 독소를 함유하는 배양원액은 곰팡이의 흰색 균사체를 노 란색의 마른 딱지로 변화시켰고, 이것은 펩티드 독소가 강력한 항진균 활성과 살균 활성을 갖고 있음을 보여준다.

Keywords 슈도모나스 톨라시· 톨라신 · 표고버섯 · 푸른곰팡 이병 · 항진균성 펩티드 독소 · Trichoderma harzianum

감사의 글 본 연구는 농림축산식품부의 재원으로 농림수산식품기술기획평 가원 농생명산업기술개발사업의 지원을 받아 연구되었음(114064-3).

\section{References}

Ait-Lahsen H, Soler A, Rey M, de La Cruz J, Monte E, Llobell A (2001) An antifungal exo-alpha-1,3-glucanase (AGN 13.1) from the biocontrol fungus Trichoderma harzianum. Appl Environ Microbiol 67: 5833-5839

Bae MJ, Kim KJ, Kim SJ, Ye EJ (2007) Effect of mycelia extracts from Lentinus edodes mushroom-cultured Astragalus membranaceus Bunge on anti-cancer and anti-allergy activities. J Kor Soc Food Sci Nutr 36: 813

Bak WC, Kwon HJ (2005) Biology and control of pests and diseases in shiitake log cultivation. Mushroom Grower's Handbook, 2nd edn. MushWorld, Seoul, pp 152-161

Cho KH, Park KS, Kim YK (2000) Hemolytic properties of tolaasin causing the brown blotch disease on oyster mushroom. J Korean Soc Agric Chem Biotechnol 43: 190-195

Cho KH, Shin DS, Kim YK (2007) Effects of mushroom extracts on the growth and pathogenicity of Pseudomonas tolaasii, a pathogenic bacterium of brown blotch disease. J Agr Sci Chungbuk Nat'l Univ 23: $133-142$
Hatvani L, Antal Z, Manczinger L, Szekeres A, Druzhinina IS, Kubicek CP, Nagy A, Nagy A, Vágvölgyi C, Kredics L (2007) Green mold diseases of Agaricus and Pleurotus spp. are caused by related but phylogenetically different Trichoderma species. Phytopathology 97: 532-537

Hatvani L, Sabolic P, Kocsube S, Kredics L, Czifra D, Vagvolgyi C, Kaliterna J, Ivic D, Dermic E, Kosalec I (2012) The first report on mushroom green mould disease in Croatia. Arh Hig Rada Toksikol 63: 481-487

Hikino H, Konno C, Mirin Y, Hayashi T (1985) Isolation and hypoglycemic activity of ganoderans $\mathrm{A}$ and $\mathrm{B}$, glycans of Ganoderma lucidum fruit bodies. Planta Med 51: 339-340

Jhune C, You CH, Cha DY, Kim GP (1990) Effects of thiabendazole on green mold, Trichoderma spp. during cultivation of oyster mushroom, Pleurotus spp. Kor J Mycol 18: 89-96

Kim JW, Kim KH, Kang HJ (1994) Studies on the pathogenic Pseudomonas causing bacterial disease of cultivated mushroom in Korea: 1. On the causal organisms of the rots of Agaricus bisporus, Pleurotus ostreatus and Lentinus edodes. Kor J Plant Pathol 10: 197-210

Kim JY, Kwon HW, Tang L, Kim SH (2012) Identification and characterization of Trichoderma citrinoviride isolated from mushroom fly-infested oak log beds used for shiitake cultivation. Plant Pathol J 28: 219

Kweon MH, Kwon ST, Kwon SH, Ma MS, Park YI (2002) Lowering effects in plasma cholesterol and body weight by mycelial extracts of two mushrooms: Agaricus blazai and Lentinus edodes. Kor J Microbiol Biotechnol 30: 402-409

Lee YS, Kim J, Lee SG, Oh E, Shin SC, Park IK (2009) Effects of plant essential oils and components from Oriental sweetgum (Liquidambar orientalis) on growth and morphogenesis of three phytopathogenic fungi. Pestic Biochem Phys 93: 138-143

Lee YS, Kim J, Shin SC, Lee SG, Park IK (2008) Antifungal activity of Myrtaceae essential oils and their components against three phytopathogenic fungi. Flavour Fragr J 23: 23-28

Miyazaki K, Tsunoda M (2003) Application of DNA marker to research on Trichoderma in mushroom facilities of Japan (1): RAPD, SSCP marker. Mushroom Sci Biotechnol 11: 65-70

Miyazaki K, Tsuchiya Y, Okuda T (2009) Specific PCR assays for the detection of Trichoderma harzianum causing green mold disease during mushroom cultivation. Mycoscience 50: 94-99

Seaby D (1998) Trichoderma as a weed mould or pathogen in mushroom cultivation. Trichoderma and Gliocladium CRC Press, London

Sullivan R, Smith JE, Rowan NJ (2006) Medicinal mushrooms and cancer therapy: translating a traditional practice into Western medicine. Perspect Bio Med 49: 159-170

Wang G, Cao X, Ma X, Guo M, Liu C, Yan L, Bian Y (2016) Diversity and effect of Trichoderma spp. associated with green mold disease on Lentinus edodes in China. Microbiologyopen 5: 709-718

Watanabe S, Kumakura K, Kato H, Iyozumi H, Togawa M, Nagayama K (2005) Identification of Trichoderma SKT-1, a biological control agent against seedborne pathogens of rice. J Gen Plant Pathol 71: 351-356

Yamamoto Y, Shirono H, Kono K, Ohashi Y (1997) Immunopotentiating activity of the water-soluble lignin rich fraction prepared from LEM-the extract of the solid culture medium of Lentinus edodes mycelia. Biosci Biotechnol Biochem 61: 1909-1912

Yun YB, Park SW, Cha JS, Kim YK (2013) Biological characterization of various strains of Pseudomonas tolaasii that causes brown blotch disease. J Korean Soc Appl Biol Chem 56: 41-45 